Table 2. Amphibian species recorded in different water bodies at Barda Wildlife Sanctuary

\section{FAUNA OF PROTECTED AREAS - 10: NOTE ON AMPHIBIANS OF BARDA WILDLIFE SANCTUARY, GUJARAT}

\section{Raju Vyas}

Sayaji Baug Zoo, Vadodara, Gujarat 390018, India

The Barda Wildlife Sanctuary $\left(21^{\circ} 42^{\prime}-21^{0} 54^{\prime} \mathrm{N} \& 69^{\circ} 39^{\prime}-69^{\circ} 49^{\prime} \mathrm{E}\right)$ an important protected areas in Gujarat was established in 1979 by the Forest Department of Gujarat. The Sanctuary is a hilly and rocky terrain with low covered vegetation. According to Champion and Seth (1968) the forest is classified as sub-group of southern tropical dry deciduous forest and northern tropical thorn forest. The climate is tropical and semi arid, monsoon is short and erratic. The average annual rainfall recorded in the last 10 years was $650 \mathrm{~mm}$. The area is drought prone. Winter is cool and dry, December and January are the coldest months during which the night temperature falls down to $8^{0}-10^{\circ} \mathrm{C}$. Summer is severe, May and June usually being the hottest months of the year with temperatures rising up to $42^{\circ} \mathrm{C}$. Information on species and status of amphibians of BWS is not available from any past relevant literature. A rapid inventory was carried out in BWS during October 2000 to June 2001. Totally, 24 days (8h/day) of day and night fieldwork were conducted in four visits to BWS covering all seasons.

In addition to the present inventory on amphibians, secondary information was gathered from local people of surrounding villages, forest personnel and wildlife enthusiasts, on different species of amphibians by interviewing and showing colour pictures of species. The entire area of $192.31 \mathrm{~km}^{2}$ was divided into small zones. Each zone was randomly explored on the basis of habitat structure, possibility and availability of the species. All important, major and minor perennial water bodies including seasonal river pools and wet pockets were extensively explored for aquatic species.

All the collected specimens were examined and, carefully identified by using diagnostic keys of Boulenger (1890), Daniel (1963a, 1963b, 1975) and Daniels (1997a, b, c). Nomenclatures

Table 1. A list of amphibians recorded at Barda Wildlife Sanctuary, Gujarat.

\begin{tabular}{|c|c|}
\hline English name & Scientific name \\
\hline $\begin{array}{l}\text { Bufonidae } \\
\text { Common Asian Toad } \\
\text { Marbled Toad }\end{array}$ & $\begin{array}{l}\text { Bufo melanostictus } \\
\text { Bufo stomaticus }\end{array}$ \\
\hline$\frac{\text { Microhylidae }}{\text { Ornate Narrow-mouthed Frog }}$ & Microhyla ornata \\
\hline $\begin{array}{l}\text { Ranidae } \\
\text { Indian Skipping Frog } \\
\text { Indian Bull Frog } \\
\text { Cricket Frog } \\
\text { Unidentified Frog } \\
\text { Short-headed Burrowing Frog } \\
\text { Indian Tree Frog }\end{array}$ & $\begin{array}{l}\text { Euphlyctis cyanophlyctis } \\
\text { Hoplobatrachus tigerinus } \\
\text { Fejervarya limnocharis } \\
\text { Fejervarya sp. } \\
\text { Sphaeroteca breviceps } \\
\text { Polypedates sp. }\end{array}$ \\
\hline
\end{tabular}

\begin{tabular}{lllllllll}
\hline Name of the water body & Bm & Bs & Mo & FI & F & Ec & Ht & P \\
\hline Dhola Ghuno & P & A & P & P & P & P & P & A \\
Kileshwar Check Dam & $\mathrm{P}$ & $\mathrm{P}$ & $\mathrm{P}$ & $\mathrm{P}$ & $\mathrm{P}$ & $\mathrm{P}$ & $\mathrm{P}$ & $\mathrm{A}$ \\
Parashiya Talaw & $\mathrm{P}$ & $\mathrm{P}$ & $\mathrm{P}$ & $\mathrm{P}$ & $\mathrm{P}$ & $\mathrm{P}$ & $\mathrm{P}$ & $\mathrm{A}$ \\
Causeway & $\mathrm{P}$ & $\mathrm{P}$ & $\mathrm{A}$ & $\mathrm{P}$ & $\mathrm{P}$ & $\mathrm{P}$ & $\mathrm{A}$ & $\mathrm{A}$ \\
Gulab Sagar & $\mathrm{P}$ & $\mathrm{P}$ & $\mathrm{A}$ & $\mathrm{P}$ & $\mathrm{P}$ & $\mathrm{P}$ & $\mathrm{P}$ & $\mathrm{A}$ \\
Sat Sagar & $\mathrm{P}$ & $\mathrm{P}$ & $\mathrm{A}$ & $\mathrm{P}$ & $\mathrm{A}$ & $\mathrm{P}$ & $\mathrm{A}$ & $\mathrm{A}$ \\
Bari Talaw & $\mathrm{P}$ & $\mathrm{P}$ & $\mathrm{P}$ & $\mathrm{P}$ & $\mathrm{P}$ & $\mathrm{P}$ & $\mathrm{P}$ & $\mathrm{A}$ \\
Fodala Nes Dam & $\mathrm{P}$ & $\mathrm{P}$ & $\mathrm{A}$ & $\mathrm{P}$ & $\mathrm{P}$ & $\mathrm{P}$ & $\mathrm{A}$ & $\mathrm{A}$ \\
Khanbhala Dam & $\mathrm{P}$ & $\mathrm{P}$ & $\mathrm{A}$ & $\mathrm{P}$ & $\mathrm{A}$ & $\mathrm{P}$ & $\mathrm{A}$ & $\mathrm{A}$ \\
Godhatad Dam & $\mathrm{P}$ & $\mathrm{P}$ & $\mathrm{A}$ & $\mathrm{P}$ & $\mathrm{P}$ & $\mathrm{P}$ & $\mathrm{A}$ & $\mathrm{A}$ \\
Aabhapara waterbodies & $\mathrm{P}$ & $\mathrm{P}$ & $\mathrm{P}$ & $\mathrm{P}$ & $\mathrm{P}$ & $\mathrm{P}$ & $\mathrm{P}$ & $\mathrm{P}$ \\
(cluster of 3) & & & & & & & & \\
Sonkansari Talaw & $\mathrm{P}$ & $\mathrm{P}$ & $\mathrm{A}$ & $\mathrm{P}$ & $\mathrm{P}$ & $\mathrm{P}$ & $\mathrm{A}$ & $\mathrm{A}$ \\
\hline
\end{tabular}

Bm - Bufo melanostictus; Bs -Bufo stomaticus; Mo - Microhyla ornata; FI - Fejervarya limnocharis; F - Fejervarya sp.; Ec - Euphlyctis cyanophlyctis; $\mathrm{Ht}$ - Hoplobatrachus tigerinus, P - Polypedates sp.; P - present; A - absent.

adopted here are those of Dutta (1997).

Totally nine species of toads and frogs belonging to three families and seven genera were recorded from the Sanctuary (Table 1), including an unidentified species belonging to genus Fejervarya. A rich amphibian diversity was recorded at Abhapara waterbodies (a cluster of three water bodies), where all the eight species of frogs and toads, including a species of tree frog belonging to Rhacophorinae subfamily was recorded. Only four species of frogs and toads were noted at Sat Sagar and Khanbhala Dam, which shows low amphibian diversity (Table 2). Most abundant anuran species found in the area were Marbled Toad (Bufo stomaticus), Common Asian Toad (Bufo melanostictus), Indian Skipping Frog (Euphlyctis cyanophlyctis), Cricket Frog (Fejervarya limnocharis) and Indian Tree Frog (Polypedates sp.). Also, few specimens of Short-headed Burrowing Frog (Sphaeroteca brviceps) were found in agricultural fields near the Bileshwar temple at the adjoining area of the Sanctuary

\section{REFERENCES}

Boulenger, G.A. (1890). The British India, including Ceylon and Burma. Reptilia and Batrachia, Taylor and Francis, xviii+541pp.

Champion, H.G. and S.K. Seth (1968). A Revised Survey of the Forest Types of India, Govt. of India, Delhi, 404pp.

Daniel, J.C. (1963a). Field guide to amphibian of western India. PartI. Journal of the Bombay Natural History Society 60: 415-438.

Daniel, J.C. (1963b). Field guide to amphibian of western India, PartII, Journal of the Bombay Natural History Society 60: 690-702.

Daniel, J.C. (1975). Field guide to amphibian of western India. PartIII. Journal of the Bombay Natural History Society 72: 506-522.

Daniels, R.J.R. (1997). A field guide to the frogs and toads of the Western Ghats, India Part I. Cobra 27: 1-25.

Daniels, R.J.R. (1997). A field guide to the frogs and toads of the Western Ghats, India Part II. Cobra 28: 1-24.

Daniels, R.J.R. (1997). A field guide to the frogs and toads of the Western Ghats, India Part III. Cobra 29: 1-13.

Dutta, S.K. (1997). Amphibians of India and Sri Lanka (Checklist and Bibliography). Odyssey publication House, Bhubaneswar, Orissa, India, 342pp.

\section{ACKNOWLedgement}

I am highly indebted to Dr. H.S. Singh, Director, Gujarat Ecological Education and Research (GEER) Foundation, Gandhinagar for their logistic help and permitting for this study.

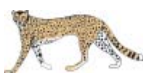

